\title{
Preferences for activities in French textbooks used in Slovak secondary schools analysed with Birova's Communication Curve Tool
}

\author{
Jana Bírová \\ Comenius University in Bratislava, Slovakia \\ birova@fedu.uniba.sk
}

\begin{abstract}
Which textbooks are used in French classes? Can the struggle to choose a good textbook affect the communication procedure in French? What is the proportion of language, intercultural and communicative activities in selected textbooks? What are the reasons for purchasing language-based and communication-based textbooks? The present study explores these questions and presents results with broad implications for teachers of French at secondary schools. It points out some significant markers such as textbook type activities preferences and arguments for choosing textbooks for French classes.
\end{abstract}

Keywords

textbooks, frequency, activities, preferences, communication, appropriateness

\section{Introduction}

Slovak state standards and curricula are becoming increasingly important not only in the implementation of instruction but also in choosing a good textbook. Many textbook publishers provide a variety of activities in order to fulfil general textbook standards without considering the balance between the intercultural importance, grammar significance and communication needs. In the paper, I present partial results from the empirical research conducted within a year. I propose a survey of textbooks used for teaching French at secondary schools in Slovakia. The objective of this study is not only to show what textbooks are used and with what frequency, but I also I intend to demonstrate that, for instance, the textbooks which are used often do not sufficiently attain the communicative objective.

When choosing a textbook, several elements should be taken into consideration - the students, the proportion of language-based and communication-based or task-based activities, the proportion of activities enhancing the students' input and output, the curricula content. Cunningsworth (1995) suggests four criteria for evaluating language textbooks. They should:

- reflect students' needs and match learning objectives,

- reflect the use of language communicatively,

- facilitate learning processes by eclecticism,

- sustain a clear role as a support for learning.

The problem which was assumed before proceeding with the research, was related to the theories, research or partial research in the works of French-writing authors such as Bertocchini and Constanzo (2008), Besse (1995), Courtillon (2003), Pécheur and Vigner (1995), Slovak-writing authors Nogová and Bálint (2005), Pokrivčáková (2003, 2004), Repka (1990) or Turek (1997), as well as Englishwriting authors Brumfit and Johnson (1989), Cunningsworth (1995), Dalgalian, Lieutaud and Weiss (1991), Daoud and Celce-Murcia (1979), Lamie (1999), Lee and Vanpatten (2005), Nunan $(1989,1991)$, Sheldon (1988), Skierso (1991), Thornbury (2006) or Tomlinson (2001) but mainly to the theory of the balance-activity approach mentioned in the work of Harmer (1991) which was the point of departure 
for creating Birova's theory of CC analysis and seen in the material coverage of everyday class in the form of the proportion of language-based exercises and communication-based activities in the textbooks which prepare high school learners for their final graduation examination in French as a foreign language.

\section{Research methodology}

Such methods as a questionnaire and interview concerning the use and the variety of French textbooks and exercise books were used with French teachers teaching at secondary schools. Birova's Communication Curve (CC) content analysis was applied in order to map communicative, language, sociolinguistic and pragmatic activities in randomly selected units of textbooks previously designed by teachers in the questionnaire. The research methodology was devised during the doctoral studies in 2009 and was discussed and published in the proceedings from the World Congress of Teachers of French in Quebec in 2008 (Bírová et al., 2010).

\section{Research objectives}

Research objectives are designed regarding the assumed problem. In the present paper, the following is intended:

- to map French textbook policy and exercise typology,

- to map the ratio between communicative, language, sociolinguistic and pragmatic activities in randomly selected units of textbooks,

- to point out some motivating factors behind teachers' choice when selecting textbooks.

\section{Research procedure and results}

Frequencies called tallies were used to count up the number of teachers and the number of textbooks. The respondents to the questionnaire turned out to be 108. 2 questionnaires were not suitable and another 6 teachers of French expressed their opinions in the questionnaire but were not currently teaching French at secondary schools. The bank of 100 questionnaires created the corpus of answers that was analysed. The respondents were from the following towns:

6 Banská Bystrica, 1 Brezno, 1 Čadca, 1 Dolný Kubín, 2 Dubnica nad Váhom, 1 Galanta, 4 Hadlová, 1 Hnúšt'a, 1 Humenné, 1 Kežmarok, 3 Komárno, 1 Košice, 1 Kremnica, 2 Krupina, 1 Levoča, 3 Liptovský Mikuláš, 2 Lučenec, 1 Martin, 2 Michalovce, 4 Námestovo, 4 Nitra, 1 Nové Mesto nad Váhom, 1 Nové Zámky, 2 Piešt’any, 2 Poprad, 2 Piešt’any, 2 Poprad, 1 Považská Bystrica, 3 Prievidza, 1 Pruské, 1 Púchov, 1 Rajec, 1 Rimavská Sobota, 1 Sabinov, 2 Senica, 2 Stropkov, 1 Tisovec, 1 Topol’čany, 8 Trenčín, 1 Trnava, 2 Tvrdošín, 1 Vrútky, 1 Zlaté Moravce, 4 Zvolen, 1 Žiar nad Hronom, 5 Žilina, 2 did not specify the town).

Total number of respondents: 100

Table 1: School typology

\begin{tabular}{|c|c|c|c|c|}
\hline 4-year high schools & $\begin{array}{c}\text { 8-year high } \\
\text { schools } \\
\text { (French CLIL } \\
\text { classes) }\end{array}$ & $\begin{array}{c}\text { Secondary } \\
\text { vocational schools }\end{array}$ & $\begin{array}{c}\text { Associated } \\
\text { secondary schools }\end{array}$ & 0thers \\
\hline 62 & 14 & 14 & 4 & 2 \\
\hline
\end{tabular}

According to the first result, the highest number of schools where teachers teach French are 4-year high schools. The development of confident communication in French takes place in 8-year high schools, too. This is due to everyday French CLIL classes. A high level of French is also at secondary vocational schools where students have to learn not only the basics of the language but they also penetrate to the specific fields of their future work. 
Table 2: Gender of respondents

\begin{tabular}{|c|c|c|c|c|c|c|c|}
\hline Gender & $\begin{array}{c}\text { 4-year } \\
\text { high } \\
\text { schools }\end{array}$ & $\begin{array}{c}\text { 8-year } \\
\text { high } \\
\text { schools } \\
\text { (French } \\
\text { CLIL } \\
\text { classes) }\end{array}$ & $\begin{array}{c}\text { Secondary } \\
\text { vocational } \\
\text { schools }\end{array}$ & $\begin{array}{l}\text { Associated } \\
\text { secondary } \\
\text { schools }\end{array}$ & Others & \multicolumn{2}{|c|}{ Total } \\
\hline Female & 61 & 14 & 18 & 3 & - & 96 & $96 \%$ \\
\hline Male & 1 & - & - & 1 & - & 2 & $2 \%$ \\
\hline Did not specify & - & - & - & - & 2 & 2 & $2 \%$ \\
\hline Total & 62 & 14 & 18 & 4 & 2 & 100 & $100 \%$ \\
\hline
\end{tabular}

As it is evident, teaching French is mainly the business of female French teachers (96\%).

The respondents are used to using more than one textbook during their classes. Sometimes it even happens that they change the publisher as they are not satisfied with the textbook policy introduced by the Ministry of Education. Some of the interviewed teachers use the textbook entitled En français 1 in the first grade. In the second grade, these teachers turn to a completely different publisher and start working with Francúzsky jazyk pre stredné školy 2. In the third and fourth grades, teachers choose for their learners the textbook entitled Forum 2. Other teachers use more than one textbook for the same level of students. For example, in the old textbook entitled Francúzsky jazyk, written according to the audiolingual method, they appreciate the grammar exercises and the system which allows learners to automatize grammatical rules. In Libre échange, teachers appreciate pre-communicative and communicative activities. During conversation lessons, teachers are used to working with thematic workbooks mentioned above.

Except percentage calculations and dividing textbooks according to the typology of schools, the textbooks were sorted by the frequency of use - from the highest to the lowest. Table 3 is a summary table of all the books (60) the interviewed teachers indicated in their questionnaires. Table 4 shows the rank of cyclic textbooks and Table 5 the percentage rank of the thematic exercise books.

The most frequently used exercise book is Oui with the representation of $28 \%$. The other two most widely used textbooks are En français 1 and En français 2. Interestingly, this set of books is designed primarily for elementary schools. Its high percentage of usage at secondary schools reflects common methods of teachers at primary and secondary schools for teaching French language as well as the similar language content and objectives at A1 and A2 levels of learning French. However, some teachers consider the use of textbooks En français and En français 2 as infantile as they are intended for lowerage audience.

Table 3: Raw frequencies and percentages of using textbooks and thematic workbooks at secondary schools in Slovakia

\begin{tabular}{|c|l|r|r|r|r|r|r|r|}
\hline \multicolumn{2}{|c|}{$\begin{array}{c}\text { Rank }{ }^{1} \text { of textbooks and } \\
\text { workbooks }\end{array}$} & $\begin{array}{c}\text { 8-year } \\
\text { 4-year } \\
\text { high } \\
\text { schools } \\
\text { high } \\
\text { schools } \\
\text { (French } \\
\text { CLIL } \\
\text { classes) }\end{array}$ & $\begin{array}{c}\text { Second } \\
\text { ary } \\
\text { vocation } \\
\text { al } \\
\text { schools } \\
\text { schocondary } \\
\text { schools }\end{array}$ & 0thers & \multicolumn{3}{|c|}{} \\
\hline 1 & Oui & 12 & 4 & 9 & 1 & 2 & 28 & $28 \%$ \\
\hline 2 & En français 1 & 3 & 9 & 5 & 2 & 1 & 20 & $20 \%$ \\
\hline 3 & En français 2 & 1 & 10 & 5 & 2 & 1 & 19 & $19 \%$ \\
\hline
\end{tabular}

\footnotetext{
${ }^{1}$ References for textbooks - see Bibliographic References
} 


\begin{tabular}{|c|c|c|c|c|c|c|c|c|}
\hline 4 & Libre échange 1 & 10 & 6 & 1 & - & - & 17 & $17 \%$ \\
\hline 5 & Forum 2 & 8 & 2 & 1 & 3 & 2 & 16 & $16 \%$ \\
\hline 6 & \begin{tabular}{|l|} 
Le Nouveau Sans \\
Fontières 1
\end{tabular} & 3 & 5 & 6 & 2 & - & 16 & $16 \%$ \\
\hline 7 & En français 3 & 1 & 6 & 4 & 1 & 1 & 13 & $13 \%$ \\
\hline 8 & Libre échange 2 & 12 & 1 & - & - & - & 13 & $13 \%$ \\
\hline 9 & Forum 1 & 7 & 1 & 2 & - & 2 & 12 & $12 \%$ \\
\hline 10 & \begin{tabular}{|l|} 
Maturujem z \\
francúzštiny 1
\end{tabular} & 7 & 1 & 2 & - & 1 & 11 & $11 \%$ \\
\hline 11 & \begin{tabular}{|l|} 
Maturujem z \\
francúzštiny 2 \\
\end{tabular} & 6 & 2 & 2 & - & 1 & 11 & $11 \%$ \\
\hline 12 & $\begin{array}{l}\text { Francúzsky jazyk pre } \\
\text { stred. školy } 3\end{array}$ & 5 & 2 & 3 & - & - & 10 & $10 \%$ \\
\hline 13 & \begin{tabular}{|l|} 
Le Nouveau Sans \\
Frontières 2 \\
\end{tabular} & 4 & 2 & - & 2 & 1 & 9 & $9 \%$ \\
\hline 14 & En français 4 & -1 & 5 & - & 2 & 1 & 8 & $8 \%$ \\
\hline 15 & $\begin{array}{l}\text { Francúzsky jazyk pre } \\
\text { stred. školy } 1\end{array}$ & 6 & - & 1 & 1 & - & 8 & $8 \%$ \\
\hline 16 & Monitor & 6 & - & 1 & - & - & 7 & $7 \%$ \\
\hline 17 & $\begin{array}{l}\text { Francúzsky jazyk pre } \\
\text { stred. školy } 2\end{array}$ & 4 & - & 1 & 2 & - & 7 & $7 \%$ \\
\hline 18 & \begin{tabular}{|l} 
En français \\
perfectionnement
\end{tabular} & 2 & - & 3 & - & - & 5 & $5 \%$ \\
\hline 19 & \begin{tabular}{|l} 
Francúzsky jazyk pre \\
stred. školy 4
\end{tabular} & 1 & - & 2 & 2 & - & 5 & $5 \%$ \\
\hline 20 & Campus 2 & 5 & - & - & - & - & 5 & $5 \%$ \\
\hline 21 & $\begin{array}{l}\text { Aspects de } \\
\text { civilisation française }\end{array}$ & 1 & - & 2 & 1 & 1 & 5 & $5 \%$ \\
\hline 22 & $\begin{array}{l}\text { Vocabulaire } \\
\text { progressif }\end{array}$ & 3 & 2 & - & - & - & 5 & $5 \%$ \\
\hline 23 & Espaces 1 & 2 & - & 2 & - & - & 4 & $4 \%$ \\
\hline 24 & Nouvel Espaces 1 & 3 & 1 & - & - & - & 4 & $4 \%$ \\
\hline 25 & $\begin{array}{l}\text { Grammaire } \\
\text { progressive }\end{array}$ & 3 & 1 & - & - & - & 4 & $4 \%$ \\
\hline 26 & Espaces 2 & 1 & 1 & 1 & - & - & 3 & $3 \%$ \\
\hline 27 & Libre échange 3 & 2 & 1 & - & - & - & 3 & $3 \%$ \\
\hline 28 & Campus 1 & 3 & - & - & - & - & 3 & $3 \%$ \\
\hline 29 & \begin{tabular}{|l|} 
Tempo 1 \\
\end{tabular} & 2 & 1 & - & - & - & 3 & $3 \%$ \\
\hline 30 & Tempo 2 & 2 & 1 & - & - & - & 3 & $3 \%$ \\
\hline 31 & On y va 1 & 1 & 1 & 1 & - & - & 3 & $3 \%$ \\
\hline 32 & On y va 2 & 1 & 1 & 1 & - & - & 3 & $3 \%$ \\
\hline 33 & Café crème 1 & 2 & - & - & - & - & 2 & $2 \%$ \\
\hline 34 & Café crème 2 & 2 & - & - & - & - & 2 & $2 \%$ \\
\hline 35 & Panorama 1 & 1 & 1 & - & - & - & 2 & $2 \%$ \\
\hline 36 & Panorama 2 & 1 & 1 & - & - & - & 2 & $2 \%$ \\
\hline 37 & Nouvel Espaces 2 & 1 & - & 1 & - & - & 2 & $2 \%$ \\
\hline 38 & On y va 3 & 1 & - & 1 & - & - & 2 & $2 \%$ \\
\hline 39 & Extra & - & 1 & 1 & - & - & 2 & $2 \%$ \\
\hline 40 & Bonne route 1 & 2 & - & - & - & - & 2 & $2 \%$ \\
\hline
\end{tabular}




\begin{tabular}{|c|c|c|c|c|c|c|c|c|}
\hline 41 & $\begin{array}{l}\text { Cvičebnice } \\
\text { francouzské } \\
\text { gramatiky }\end{array}$ & 2 & - & - & - & - & 2 & $2 \%$ \\
\hline 42 & Junior 1 & - & 1 & - & - & - & 2 & $2 \%$ \\
\hline 43 & $\begin{array}{l}\text { Francúzska } \\
\text { konverzácia }\end{array}$ & - & - & 1 & 1 & - & 2 & $2 \%$ \\
\hline 44 & Café crème 3 & 1 & - & - & - & - & 1 & $1 \%$ \\
\hline 45 & Champion 1 & - & - & 1 & - & - & 1 & $1 \%$ \\
\hline 46 & Champion 2 & - & - & 1 & - & - & 1 & $1 \%$ \\
\hline 47 & On y va 4 & 1 & - & - & - & - & 1 & $1 \%$ \\
\hline 48 & Le français pour vous & 1 & - & - & - & - & 1 & $1 \%$ \\
\hline 49 & Junior 2 & - & 1 & - & - & - & 1 & $1 \%$ \\
\hline 50 & Junior 3 & - & 1 & - & - & - & 1 & $1 \%$ \\
\hline 51 & Fréquence jeunes & - & 1 & - & - & - & 1 & $1 \%$ \\
\hline 52 & $\begin{array}{l}\text { Le Nouveau Sans } \\
\text { Frontières } 3\end{array}$ & 1 & - & - & - & - & 1 & $1 \%$ \\
\hline 53 & Archipel & - & - & - & 1 & - & 1 & $1 \%$ \\
\hline 54 & Escales & - & - & 1 & - & - & 1 & $1 \%$ \\
\hline 55 & Économie & - & - & 1 & - & - & 1 & $1 \%$ \\
\hline 56 & $\begin{array}{l}\text { Le français de } \\
\text { I’hôtelerie et de la } \\
\text { restauration }\end{array}$ & - & - & 1 & - & - & 1 & $1 \%$ \\
\hline 57 & Delf scolaire A2 & - & 1 & - & - & - & 1 & $1 \%$ \\
\hline 58 & Delf scolaire B1 & - & 1 & - & - & - & 1 & $1 \%$ \\
\hline 59 & Delf scolaire B2 & - & 1 & - & - & - & 1 & $1 \%$ \\
\hline 60 & $\begin{array}{l}\text { Francúzština pre } \\
\text { pokročilých }\end{array}$ & 1 & - & - & - & - & 1 & $1 \%$ \\
\hline
\end{tabular}

High values of usage also represent the following textbooks Libre échange, Forum, Le Nouveau Sans Frontières as well as the textbook conceived according to the audiolingual method principles, Francúzsky jazyk pre stredné školy, which was used before 1989. It is surprising that this textbook published for the first time in the 80s of the last century, the era of communism, it is still used. This might be explained as a very weak progress in the textbook policy, yet according to the interviews done with teachers during the research, this textbook is used nowadays for its grammar and, in broadest terms, linguistic know-how which is necessary mainly at the stage of language practice. While other textbooks reveal high interest in communication practice, this old audiolingual textbook is appreciated for its grammar. Teachers recommend this textbook to other colleagues as they are convinced that only with grammar exercises and pre-communicative activities a learner will know how to communicate efficiently.

As it is shown further, Maturujem z francúzštiny po novom, Monitor and En français perfectionnement achieve high representation. These books prepare high school graduates for the final examination not only from the point of view of their thematicity but also exercise typology. Other books in the stated order: Aspects de Civilisation Française, Vocabulaire progressif and Grammaire française, achieving 5\% representation.

Table 4: Percentages of French textbooks usage at secondary schools in Slovakia

\begin{tabular}{|c|l|r|r|l|lr|}
\hline \multicolumn{2}{|c|}{$\begin{array}{c}\text { Percentage of } \\
\text { French textbooks }\end{array}$} & Total & \multicolumn{2}{c|}{$\begin{array}{c}\text { Percentage of } \\
\text { French textbooks }\end{array}$} & \multicolumn{2}{c|}{ Total } \\
\hline 1 & En français 1 & $20 \%$ & 24 & On y va 2 & $3 \%$ \\
\hline
\end{tabular}




\begin{tabular}{|c|l|r|r|l|r|}
\hline 2 & En français 2 & $19 \%$ & 25 & Café crème 1 & $2 \%$ \\
\hline 3 & Libre échange 1 & $17 \%$ & 26 & Café crème 2 & $2 \%$ \\
\hline 4 & Forum 2 & $16 \%$ & 27 & Panorama 1 & $2 \%$ \\
\hline 5 & Le Nouveau S. Frontières 1 & $16 \%$ & 28 & Panorama 2 & $2 \%$ \\
\hline 6 & En français 3 & $13 \%$ & 29 & Nouvel Espaces 2 & $2 \%$ \\
\hline 7 & Libre échange 2 & $13 \%$ & 30 & On y va 3 & $2 \%$ \\
\hline 8 & Forum 1 & $12 \%$ & 31 & Extra & $2 \%$ \\
\hline 9 & Francúz. jazyk pre stred. školy 3 & $10 \%$ & 32 & Bonne route 1 & $2 \%$ \\
\hline 10 & Le Nouveau S. Frontières 2 & $9 \%$ & 33 & Junior 1 & $2 \%$ \\
\hline 11 & En français 4 & $8 \%$ & 34 & Café crème 3 & $1 \%$ \\
\hline 12 & Francúzsky jazyk pre stredné školy 1 & $8 \%$ & 35 & Champion 1 & $1 \%$ \\
\hline 13 & Francúzsky jazyk pre stredné školy 2 & $7 \%$ & 36 & Champion 2 & $1 \%$ \\
\hline 14 & Francúzsky jazyk pre stredné školy 4 & $5 \%$ & 37 & On y va 4 & $1 \%$ \\
\hline 15 & Campus 2 & $5 \%$ & 38 & Le français pour vous & $1 \%$ \\
\hline 16 & Espaces 1 & $4 \%$ & 39 & Junior 2 & $1 \%$ \\
\hline 17 & Nouvel Espaces 1 & $4 \%$ & 40 & Junior 3 & $1 \%$ \\
\hline 18 & Espaces 2 & $3 \%$ & 41 & Fréquence jeunes & $1 \%$ \\
\hline 19 & Libre échange 3 & $3 \%$ & 42 & Le Nouveau S. Frontières 3 & $1 \%$ \\
\hline 20 & Campus 1 & $3 \%$ & 43 & Archipel & $1 \%$ \\
\hline 21 & Tempo 1 & & 44 & Le français de I’hôtelerie et de & $1 \%$ \\
\cline { 2 - 5 } & & $3 \%$ & 45 & Escales & $1 \%$ \\
\hline 22 & Tempo 2 & $3 \%$ & 46 & Francúzština pre pokročilých & $1 \%$ \\
\hline 23 & On y va 1 & & & \\
\hline
\end{tabular}

Table 5: Percentages of French thematic exercise books usage at secondary schools in Slovakia

\begin{tabular}{|c|c|c|c|c|c|}
\hline \multicolumn{2}{|r|}{$\begin{array}{l}\text { Percentage of } \\
\text { French thematic exercise books }\end{array}$} & \multirow{2}{*}{$\begin{array}{l}\text { Total } \\
28 \%\end{array}$} & \multicolumn{2}{|r|}{$\begin{array}{c}\text { Percentage of } \\
\text { French thematic exercise books }\end{array}$} & \multirow[t]{2}{*}{ Total } \\
\hline 1 & Oui & & 9 & $\begin{array}{l}\text { Cvičebnice francouzské } \\
\text { gramatiky }\end{array}$ & \\
\hline 2 & Maturujem z francúzštiny 1 & $11 \%$ & 10 & Francúzska konverzácia & $2 \%$ \\
\hline 3 & Maturujem z francúzštiny 2 & $11 \%$ & 11 & Économie & $2 \%$ \\
\hline 4 & Monitor & $7 \%$ & 13 & & \\
\hline 5 & En français perfectionnement & $5 \%$ & & Delf scolaire A2 & $1 \%$ \\
\hline 6 & Aspects de civilisation française & $5 \%$ & 14 & Delf scolaire B1 & $1 \%$ \\
\hline 7 & Vocabulaire progressif & $5 \%$ & 15 & & \\
\hline 8 & Grammaire progressive & $4 \%$ & & Delf scolaire B2 & $1 \%$ \\
\hline
\end{tabular}

\section{Communication Curve (CC) Content Analysis}

In order to map activity preferences of textbooks used for teaching French at secondary schools, the Communication Curve Content Analysis (Birova, 2009) was applied. Preferences were counted upon defined categories. Activity categories were extended from 1 to 7 . Language exercises practising language without being put into context were levelled 1. Exercises practising sociolinguistic elements or 
sociocultural items without context were levelled 2. With the level 3 were associated activities which concerned pragmatic competence elements practice. These elements were predominately put into micro-contexts and represented by short open answer tasks. The fourth curve degree represented precommunicative contextual activities practising reading comprehension, listening comprehension or mediation. The fifth category represented activities which stimulated learners to work in context with elements of sociolinguistics and socioculture, also practising reading or listening. The sixth degree was oriented on contextual pragmatic activities.

The highest-level 7 incorporates production activities such as speaking, writing or oral and written interactions that encourage learners to communicate in dialogues, discussions or confrontations.

Point 0 on the CC involves extra activities that are neither open nor closed, of no linguistic or communicative relatedness. They appeared in textbooks as supplementary and had no point common with language learning (example of such assignments: "Hang the project on the board!")

The following tables present the preferred degree of activities in selected textbooks.

Table 6: Activity preferences and value scale measured by the CC content analysis in selected thematic exercise books

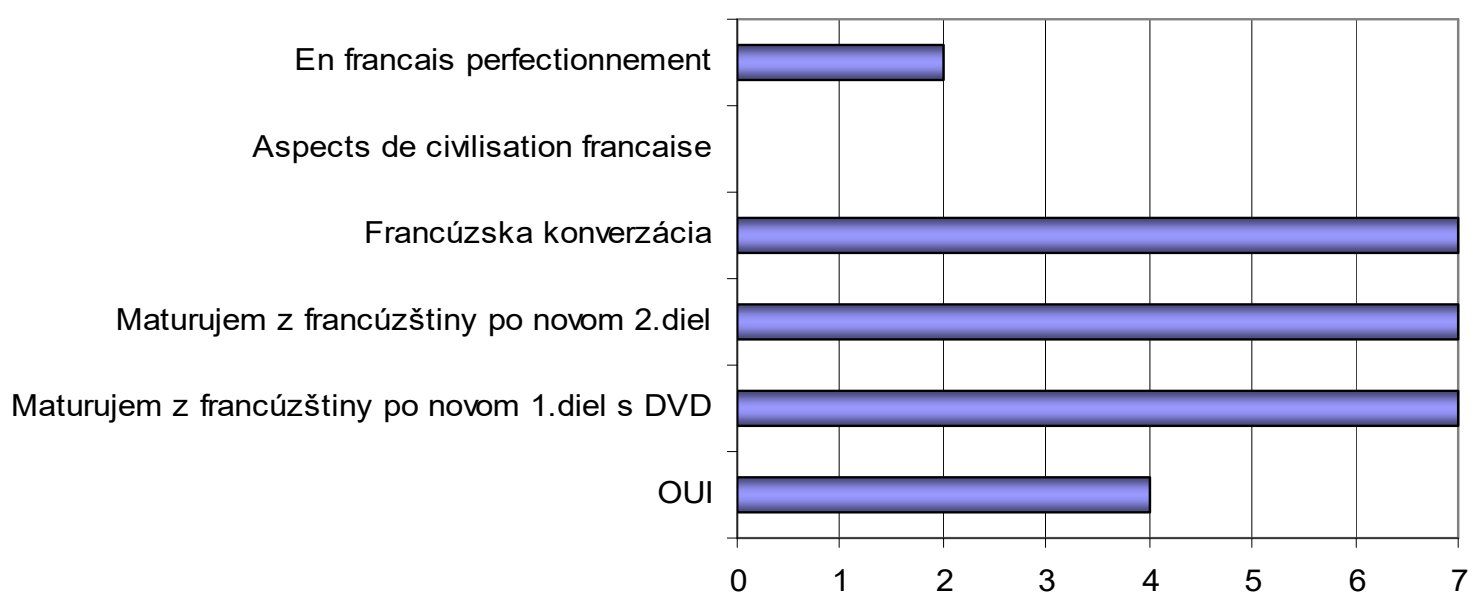

Table 6 presents the preferable aspects of thematic exercise books. While En francais perfectionnement attains only level 2 of CC analysis (activities about socioculture and sociolinguistics), Maturujem po novom exercise book set prefers communicative activities (level 7 of CC). Oui obtains level 4. Aspects de civilisation francaise seems to have not been evaluated as its preferences are not demonstrated. It is due to the authorial concept of the book as the authors decided not to invent activities, just to present texts and prepare some extracts of realia input. 
Table 7: Activity preferences and value scale measured by the CC analysis in a student's book of selected textbooks

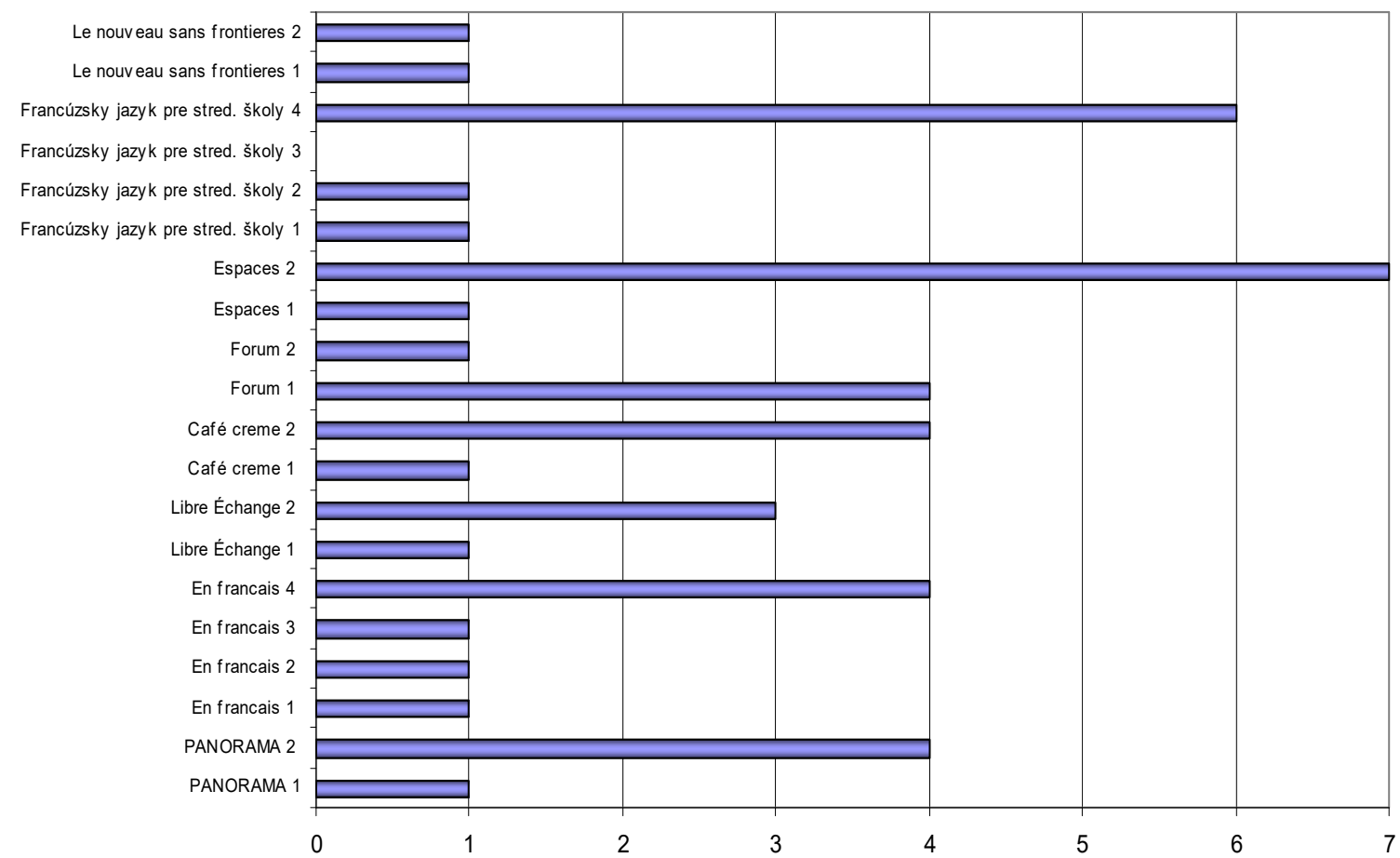

Table 8: Activity preferences and value scale measured by the CC content analysis in workbooks of selected textbooks

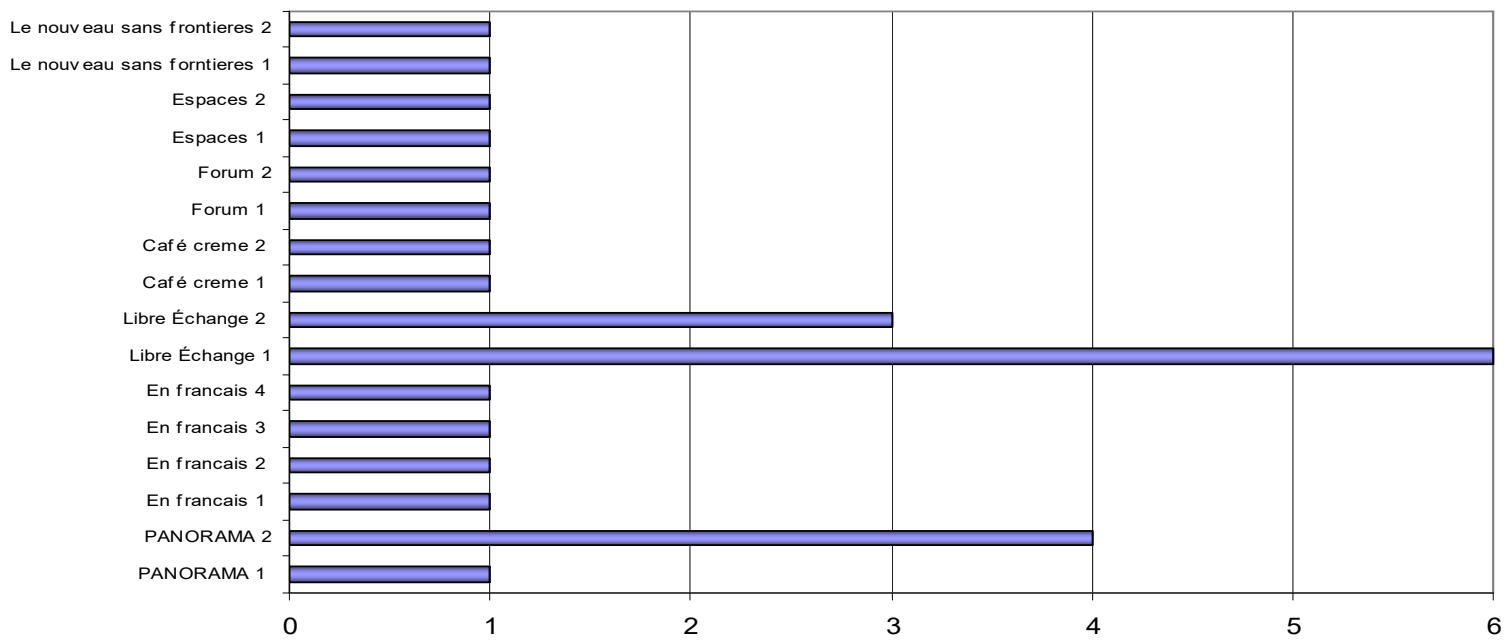


Table 9: A general overview

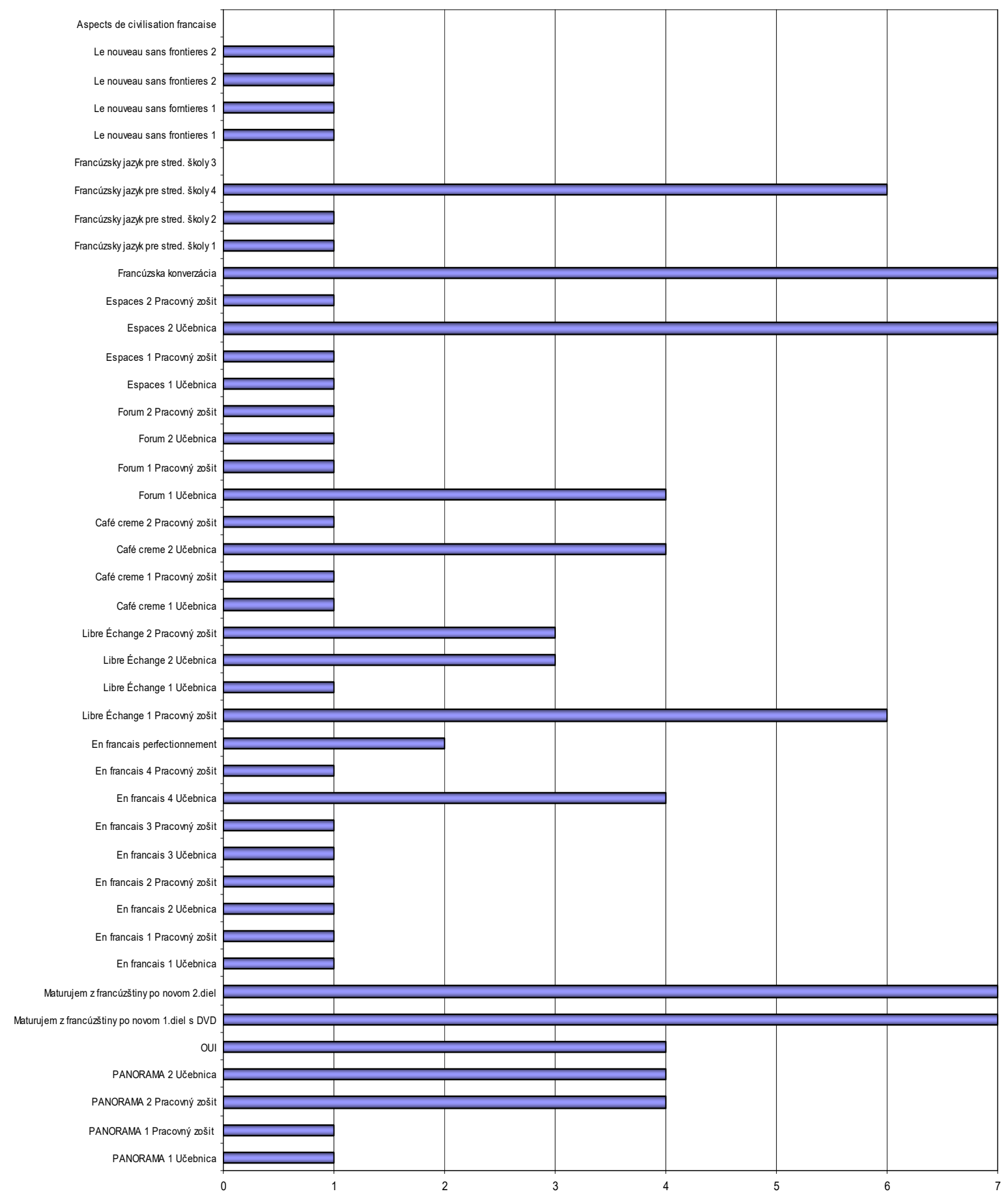


Table 10: Raw frequencies of oral communicative interaction activities and other communicative activities

\begin{tabular}{|c|c|c|c|c|}
\hline & French textbook or exercise book title & $\begin{array}{c}\mathrm{N} \\
\text { Oral } \\
\text { communicative } \\
\text { intercultural } \\
\text { interaction } \\
\text { activities } \\
\end{array}$ & $\begin{array}{c}\mathrm{N} \\
\text { Other } \\
\text { communicative } \\
\text { activities }\end{array}$ & $\begin{array}{c}\mathrm{N} \\
\text { Total } \\
\text { Communicative activities }\end{array}$ \\
\hline 1. & Forum 2 & 13 & 6 & 19 \\
\hline 2. & Forum 1 & 8 & 3 & 11 \\
\hline 3. & Espaces 2 & 7 & 12 & 19 \\
\hline \multirow{3}{*}{4.} & Café crème 1 & 7 & 2 & $\overline{9}$ \\
\hline & Café crème 2 & 5 & 3 & 8 \\
\hline & Le nouveau sans frontières 1 & 5 & 8 & 13 \\
\hline \multirow{2}{*}{5.} & Espaces 1 & 4 & 1 & 5 \\
\hline & Libre échange 2 & 4 & 7 & 11 \\
\hline \multirow{3}{*}{6.} & Francúzska konverzácia & 3 & 3 & 6 \\
\hline & Maturujem z francúzštiny po novom 1 & 3 & 16 & 19 \\
\hline & Maturujem z francúzštiny po novom 2 & 3 & 10 & 13 \\
\hline \multirow{6}{*}{7.} & En français 1 & 2 & 1 & 3 \\
\hline & En français 2 & 2 & 7 & 9 \\
\hline & En français 3 & 2 & 3 & 5 \\
\hline & Libre échange 1 & 2 & 0 & 2 \\
\hline & Panorama 1 & 2 & 4 & 6 \\
\hline & Panorama 2 & 2 & 4 & 6 \\
\hline \multirow{2}{*}{8.} & En français 4 & 1 & 5 & 6 \\
\hline & Le nouveau sans frontières 2 & 1 & 7 & 8 \\
\hline \multirow{8}{*}{9.} & En français perfectionnement & 0 & 0 & 0 \\
\hline & Franc.jazyk pre stred.školy 1 & 0 & 2 & 2 \\
\hline & Franc.jazyk pre stred.školy 2 & 0 & 0 & 0 \\
\hline & Franc.jazyk pre stred.školy 3 & 0 & 0 & 0 \\
\hline & Franc.jazyk pre stred.školy 4 & 0 & 3 & 3 \\
\hline & Aspects de civilisation française & 0 & 0 & 0 \\
\hline & Oui - francúzština cvičebnica & 0 & 0 & 0 \\
\hline & Total & 76 & 107 & 183 \\
\hline
\end{tabular}

Oui, a thematic exercise book purchased and used widely in Slovakia in order to prepare future high school graduates for the final examination achieves only level 4 of communicativeness. Analysing the data collected in the chart below, the book does not eliminate oral interaction activities. Why, then, do teachers use this thematic workbook if not for preparing students for communication? According to the data collected from interviews, teachers are used to using the audiolingual method principles. They let learners memorise texts which are, then, learnt by heart. This principle teaches them to reproduce written texts.

Another thematic exercise book designed to develop communication aspects is Aspects de civilisation francaise. The book conceptors did not include any exercise or any activity. The book consists of sociocultural elements packed in a number of texts.

Francúzsky jazyk pre stredné školy 1, 2, 3, 4 - a set of textbooks conceived upon the audiolingual method principles, inadequately proposes improvement possibilities regarding intercultural communication in interaction. Books following the communicative approach principles reveal a high interest in the development of students' conversational potential by means of information gap activities or tasks involving speech acts. These are Espaces 2, Francúzska konverzácia and the thematic exercise books Maturujem z francúzštiny po novom 1 and 2. 
When investigating further the authorial preferences in the aforementioned textbooks, it is surprising that not infrequently there is a small or no difference between the textbook and its corresponding workbook. Panorama 1 textbook and Panorama 1 workbook, for example, have the same level of the CC activity preferences - level 1 . As a researcher, I ask then: what are the reasons and, more importantly, what are the learners' benefits of the stated identical textbook conceptualization? Panorama 2 follows the same pattern as both the textbook as well as the workbook are also on the same CC level 4. Consequently, it is only language-based activities, mostly contextualised, that are incorporated, either through reading or listening practice. Hardly any or no opportunity is given to practise oral interaction or pragmatic linguistics.

In the set of textbooks Forum (Forum 1, Forum 2), the randomly selected unit to be evaluated in Forum 2 consisted of more than 50 exercises and activities out of which 13 propose to practise oral intercultural interaction. 6 other are considered as other communicative activities. They enhance learners' speaking and writing skills. In chart 1 Forum 2 is considered as one of the most communicative textbooks so far as presented in the tables 7 and 8 . This is because the tables 6,7 and 8 reveal only textbook preferences. The authors of forum 2 preferred in the selected unit the CC level 1. It means that in the mentioned unit, learners are to practise communicative activities but they are more exposed to non-contextual language-based activities, as, for example, putting the verbs in brackets into the correct form in isolated sentences.)

The set of cyclic textbooks En francais 1, 2, 3, 4 as well as Perfectionnement are also conceived in accordance with the communicative approach principles but the results of the CC content analysis do not validate this statement. The authors were much inspired by the audiolingual method principles. Teachers mentioned in the interview that for this set of textbooks, it is very difficult to get listening activities records. They admit omitting these activities in the class.

\section{Conclusion}

Textbooks are in the policy as terms to describe learning support materials. Creating a textbook includes several stages and implements a variety of aspects. The process itself in bringing textbooks from the hands of the author (or conceptor) to the user (teachers and learners) aims to pave the way forward for learners in formal education to have access to learning support materials. Textbooks aim to develop to their full potential in order to make a meaningful contribution to the economic development. The economic and access criterion is sometimes a way to influence teachers' decision. Sometimes, the policy missions of creating a good textbook to plan and implement integrated, sustainable and coordinated learning support materials supply the chain that will provide the best value, curriculumrelevant textbooks in an equitable way to all learners and teachers. This should have a direct and measurable impact on the quality of learning opportunities for all learners.

In the article, the equitable way was measured by the aid of the $\mathrm{CC}$ analysis and it was shown that textbooks more commonly purchased do not positively answer the demand of the equal proportion of activities. The most used textbooks were evaluated as the least communicative.

The stated research outcomes lead researchers and teachers of French to reconsider the level of efficiency when using textbooks in class. The Slovak textbook policy is an unrestricted process and does not limit teachers' freedom to choose suitable materials; however the process itself seems to be difficult and inefficient.

\section{Acknowledgement}

The study is the partial result of the project VEGA 1/0106/15 2015-2017 "Teoretické skúmanie a empirické overenie konceptu interkultúrnej komunikatívnej kompetencie ako súčasti aktuálnej koncepcie výučby ciel'ových jazykov v súčinnosti so Spoločným európskym referenčným rámcom pre jazyky: učenie, vyučovanie, hodnotenie" funded by the Ministry of Education, Science, Research, and Sport of the Slovak Republic. 


\section{References}

AMINEVA, V. (2015). Phenomenon of border in interliterary dialogue. XLinguae, 6(2), 246-249. DOI: $10.7813 /$ jll.2015/6-2/52.

BAYLON, C., CAMPA, A., MESTREIT, C., MURILLO, J., \& TOST, M. (2000). Forum 1. Hachette FLE.

BAYLON, C., CAMPA, A., MESTREIT, C., MURILlO, J., \& TOST, M. (2000). Forum 1. Cahier d'exercices. Hachette FLE.

BERTOCCHINI, P. \& CONSTANZO, E. (2008). Manuel de formation pratique pour le professeur de FLE. CLE International.

BESSE, H. (1995). Méthodes et pratiques des manuels de langue. Didier.

BÍROVÁ, J. (2005). Maturujem z francúzštiny po novom + DVD 1. diel. Vzdelávanie Don Bosca.

BÍROVÁ, J. (2006). Maturujem z francúzštiny po novom + DVD 2. diel. Vzdelávanie Don Bosca.

BÍROVÁ, J. (2009). Komunikatívny ciel’ v typológii učebnicových úloh a úloh na maturitnej skúške z francúzskeho jazyka. PhD. thesis. Bratislava: Comenius University.

BÍROVÁ, J. et al. (2010). Les réformes dans l'enseignement des langues étrangeres en SLovaquie ne déforment-elles pas le but de l'apprentissage? Dialogues et cultures : Faire vivre les identités francophones, Actes du XXIIe congres mondial de la FIPF, Québec 21-25 juillet 2008. Tome I: Enjeux socio-politiques, 55, 67-78.

BRUMFIT, C. J. \& JOHNSON, K. (1989). The communicative Approach to Language Teaching. Oxford: OUP. CAMPA, A., MESTREIT, C., MURILLO, J., \& TOST, M. (2001). Forum 2. Hachette FLE.

CAMPA, A., MESTREIT, C., MURILLO, J., \& TOST, M. (2001). Forum 2. Cahier d'exercices. Hachette FLE.

CAPELLE, G. \& GIDON, N. (1995). Espaces 1. Hachette International.

CAPELLE, G. \& GIDON, N. (1995). Espaces 1. Cahier d'exercices. Hachette International.

CAPELLE, G. \& GIDON, N. (1995). Espaces 2. Hachette International.

CAPELLE, G. \& GIDON, N. (1995). Espaces 2. Cahier d'exercices. Hachette International.

CHISS, J.-L., DAVID, J., \& REUTER, Y. (1995). Didactique du français. Nathan.

COURTILLON, J. (2003). Élaborer un cours de FLE. Hachette.

COURTILLON, J. \& SALINS, G.-D. (2003). Libre échange 1. Didier/Hatier.

COURTILLON, J. \& SALINS, G.-D. (2003). Libre échange 1. Cahier d'exercices. Didier/Hatier.

COURTILLON, J. \& SALINS, G.-D. (1998). Libre échange 2. Didier/Hatier.

COURTILLON, J. \& SALINS, G.-D. (1998). Libre échange 2. Cahier d'exercices. Didier/Hatier.

CUNNINGSWORTH, A. (1995). Choosing your coursebook. Oxford: Heinmann.

CUQ, J.-P. (2003). Dictionnaire de didactique du français langue étrangère. CLE International.

DALGALIAN, G., LIEUTAUD, S., \& WEISS, F. (1991). Pour un nouvel enseignement des langues. CLE International.

DAOUD, A. \& CELCE-MURCIA, M. (1979). Selecting and evaluating a textbook. In Celce-Murcia, M. \& McIntosh, L. (Eds.), Teaching English as a second or foreign language (p. 302-307). Cambridge, MA: Newbury House Publishers.

DOULIK, P., SKODA, J., \& RICAN, J. (2015). Metacognitive Strategies: Asset to Efficient Learning and Education. Slavonic Pedagogical Studies Journal, 4(1), 62-81. DOI: 10.18355/PG.2015.4.1.62-81.

GAVORA, P. (1999). Úvod do pedagogického výskumu. Bratislava: UK.

GERMAIN, C. (1993). Évolution de l'enseignement des langues : 5000 ans d'histoire. Paris: CLE international.

GIRARDET, J., DOMINIQUE, P., \& VRIES, C. P. (2002). Le Nouveau Sans Frontières 1. CLE International.

GIRARDET, J., DOMINIQUE, P., \& VRIES, C. P. (2002). Le Nouveau Sans Frontières 1. Cahier d'exercices. CLE International.

GIRARDET, J., DOMINIQUE, P., \& VRIES, C. P. (2002). Le Nouveau Sans Frontières 2. CLE International.

GIRARDET, J., DOMINIQUE, P., \& VRIES, C. P. (2002). Le Nouveau Sans Frontières 2. Cahier d'exercices. CLE International.

GIRARDET, J. \& CRIDLIG, J.-M. (2004). Panorama 1. CLE International.

GIRARDET, J. \& CRIDLIG, J.-M. (2004). Panorama 1. Cahier d'exercices. CLE International. 
GIRARDET, J. \& CRIDLIG, J.-M. (2004). Panorama 2. CLE International.

GIRARDET, J. \& CRIDLIG, J.-M. (2004). Panorama 2. Cahier d'exercices. CLE International.

GOMEZ-PABLOS, B. (2014). Didáctica de ELE : Fundamentos de didáctica. Nümbrecht : Kirsch-Verlag.

HARMER, J. (1998). How to Teach English. New York: Longman.

HARMER, J. (1991). The Practice of Engllish Language Teaching. New York: Longman.

KANEMAN, M., TREVISI, S., \& BEACCO DI GIURA, M. (1997). Café crème 1. Hachette Livre.

KANEMAN, M., TREVISI, S., \& BEACCO DI GIURA, M. (1997). Café crème 1. Cahier d'exercices. Hachette Livre.

KANEMAN, M., TREVISI, S., \& BEACCO DI GIURA, M. (1997). Café crème 2. Hachette Livre.

KANEMAN, M., TREVISI, S., \& BEACCO DI GIURA, M. (1997). Café crème 2. Cahier d'exercices. Hachette Livre.

LAMIE, J. M. (1999). Making the textbook more communicative. The Internal TESL Journal, 5(1). Retrieved September 27, 2010, from www.iteslj.org

LEE, J. F. \& VANPATTEN, B. (2005). Making Communicative Language Teaching Happen. New York: McGraw-Hill, Inc.

LYNCH, T. \& ANDERSON, K. (1992). Study Speaking. Cambridge: CUP.

MALAMAH-THOMAS, A. (1987). Classroom Interaction. Oxford: OUP.

MALOVECKÝ, M. (2014). Lingvistické komponenty hl'adania metódy v kontrastívnej jazykovede. In Hladanie metódy v kontrastívnej lingvistike (p. 12-32). Bratislava: Univerzita Komenského.

MALOVECKÝ, M. (2015). Intercultural context in translation of proper nouns. XLinguae, 8(4), 10-14. DOI: $10.18355 /$ XL.2015.08.04.10-14.

MÁTÉFFYOVÁ, E., BOURSIER, M., \& ŠVARBOVÁ, E. (2005). Oui - Francúzština cvičebnica s CD. Nitra: Enigma.

MEDVECZKÁ, M. (2007). Vyučovanie cudzích jazykov vo vybraných krajinách Európy Španielsko. In Koncepcia vyučovania cudzích jazykov $v$ základných a stredných školách: prehíbenie efektívnosti vyučovania cudzích jazykov v súvislosti so vstupom Slovenska do EÚ (p. 47-49). Bratislava: Štátny pedagogický ústav.

NOGOVÁ, M. \& BÁLINT, L. (2005). Metodická príručka ku kritériám na hodnotenie kvality učebníc. Bratislava: ŠPÚ.

NUNAN, D. (1989). Designing Tasks for the Communicative Classroom. Cambridge: CUP.

NUNAN, D. (1991). Language teaching Methodology. Phoenix: ELT.

PÉCHEUR, J. \& VIGNER, G. (1995). Méthodes et méthodologies. Paris: EDICEF.

PETLÁK, E. (1997). Všeobecná didaktika. Bratislava: Iris.

PETLÁK, E. \& KOMORA, J.: Vyučovanie v otázkach a odpovediach. Bratislava: Iris.

POKRIVČÁKOVÁ, S. (2003). Nová pozícia učebnice v prostredí multimediálneho vzdelávania. In Cudzie jazyky v škole: Didaktická efektívnost' učebníc cudzieho jazyka (p. 73-77). Nitra: UKF.

POKRIVČÁKOVÁ, S. (2004). K modernizácii a hodnoteniu vysokoškolských učebných textov. In Pedagogická konferencia VII. Aktuálne otázky výchovy a vzdelávania v období vstupovania do EÚ (p. 167-176). Nitra: UKF.

POKRIVČÁKOVÁ, S. (2006). Štruktúra vnútornej motivácie mladších žiakov k učeniu sa cudzích jazykov. In Petlák, E. et al., Pedagogicko-didaktické požiadavky motivácie žiakov do učebnej činnosti (p. 50-53). Nitra: UKF.

POKRIVČÁKOVÁ, S., DUCHOVIČOVÁ, J. et al. (2009). Cudzie jazyky a kultúry v modernej škole. Brno: Masarykova univerzita.

POKRIVČÁKOVÁ, S. (2013). Applied Linguistics Research of Bilingualism and its Incentives for Foreign Language Pedagogy. Journal of Language and Cultural Education, 1(1), 51-62.

POKRIVČÁKOVÁ, S. (2014). Code-switching ako lingvodidaktický fenomén. XLinguae, 7(2), 61-74.

PRAVDA, M. \& PRAVDOVÁ, M. (1996). Francúzska konverzácia. Bratislava: SPN.

REPKA, R. (1990). Niektoré otázky teórie a praxe tvorby učebníc. Zborník referátov zo seminára VÚPaP v Bratislave (p. 49-59). Bratislava: VÚPaP. 
RICHARDS, J. C. \& RODGERS, S. T. (1986). Approaches and Methods in Language Teaching. Cambridge: CUP.

ROVENSKÁ, Z. (1998). Aspects de civilisation française. Alter ego.

SAVIGNON, S. J. (1983). Communicative Competence: Theory and Classroom Practice. Addison-Wesley Publishing Company, Inc.

SHELDON, L. E. (1988). Evaluating ELT textbooks and materials. English Language Teaching Journal, 42(4), 237-246.

SKIERSO, A. (1991). Textbook selection and evaluation. In Celce-Murcia, M. (Ed.), Teaching English as a second or foreign language. Boston: Heinle \& Heinle.

ŠIMKOVÁ, Z. (2014). Klasické vyučovanie cudzích jazykov v porovnaní s inovatívnymi prístupmi. Studi Italo - Slovacchi, 3(1), 207-212.

ŠIMKOVÁ, Z. (2015). Learning styles and strategies. Slavonic pedagogical studies journal, 4(1), 82-88. DOI: $10.18355 / P G .2015 .4 .1 .82-88$

ŠIMKOVÁ, Z. (2015). Developing Additive Bilingualism of Very Young Learners of English. In: Language, Literature and Culture in Education 2015: Proceedings from International Conference (p. 159-166). Nitra: SlovakEdu.

TAIŠLOVÁ, J., BARANOVÁ, E. \& CLUSE, J.-L. (1995). En français 1. Bratislava: SPN/Hachette Livre.

TAIŠLOVÁ, J., BARANOVÁ, E. \& CLUSE, J.-L. (1995). En français 1. Pracovný zošit. Bratislava: SPN/Hachette Livre.

TAIŠLOVÁ, J., BARANOVÁ, E. \& CLUSE, J.-L. (1995). En français 2. Bratislava: SPN/Hachette Livre.

TAIŠLOVÁ, J., BARANOVÁ, E. \& CLUSE, J.-L. (1995). En français 2. Pracovný zošit. Bratislava: SPN/Hachette Livre.

TAIŠLOVÁ, J., BARANOVÁ, E. \& CLUSE, J.-L. (2000). En français 3. Bratislava: SPN/Hachette Livre.

TAIŠLOVÁ, J., BARANOVÁ, E. \& CLUSE, J.-L. (2000). En français 3. Pracovný zošit. Bratislava: SPN/Hachette Livre.

TAIŠLOVÁ, J., BARANOVÁ, E. \& CLUSE, J.-L. (1994). En français 4. Bratislava: SPN/Hachette Livre.

TAIŠLOVÁ, J., BARANOVÁ, E. \& CLUSE, J.-L. (1994). En français 4. Pracovný zošit. Bratislava: SPN/Hachette Livre.

TAIŠLOVÁ, J., BARANOVÁ, E. \& CLUSE, J.-L. (1996). En français perfectionnement. Bratislava: SPN/Hachette Livre.

TAIŠLOVÁ, J., BARTOŠ, J. \& HORAŽĎOVSKÁ, R. (1984). Francúzsky jazyk pre stredné školy 1. Bratislava: SPN.

TAIŠLOVÁ, J., BARTOŠ, J. \& HORAŽĎOVSKÁ, R. (1985). Francúzsky jazyk pre stredné školy 2. Bratislava: SPN.

TAIŠLOVÁ, J., JÓNOVÁ, R. \& HORAŽĎOVSKÁ, R. (1986). Francúzsky jazyk pre stredné školy 3. Bratislava: SPN.

TAIŠLOVÁ, J., JÓNOVÁ, R. \& HORAŽĎOVSKÁ, R. (1987). Francúzsky jazyk pre stredné školy 4. Bratislava: SPN.

THORNBURY, S. (2006). How to Teach Speaking. UK: Longman.

TOMLINSON, B. (2001). Materials development. Carter, R. \& Nunan, D. (Eds.), The Cambridge guide to teaching. English to speakers of other languages (p. 66-71). Cambridge: CUP.

TUREK, I. (1997). Zvyšovanie efektívnosti vyučovania. Bratislava: MPC.

VASBIEVA, D. \& KLIMOVA, I. (2015). Transformational Potential of Blended Learning to Personalize Foreign Language Teaching in a Non-Linguistic Higher School. XLinguae, 8(1), 2-10. DOI: 10.18355/XL.2015.08.01.2-10

WIDDOWSON, H. G. (1978). Une approche communicative de l'enseignement des langues. Hatier/Didier. ZUJEV, D. (1986) Ako tvorit' učebnice. Bratislava: SPN. 


\section{Contact}

Doc. PaedDr. Jana Bírová, PhD.

Department of Romance Languages and Literatures

Faculty of Education

Comenius University, Bratislava

Račianska 59, Bratislava, Slovakia

birova@fedu.uniba.sk 